\title{
E-loyalty Model in e-Commerce
}

\author{
Amir Afsar \\ Assistant professor, University of Qom, Iran
}

Zeinab Nasiri

MS, University of Qom, Iran

Mahboubeh Ostad Zadeh

Ph.D candidate, Ferdowsi University of Mashhad, Iran

\section{Doi:10.5901/mjss.2013.v4n9p547}

\begin{abstract}
Companies based on Internet should remain competitive. One of ways of modified competitive advantage is the attraction of most customers and the increase of customer retention. In emerging commercial competitions, customer loyalty is an important characteristic for obtaining the continuation of competitive advantage. The purpose of this research is to show a theoretical model for the identification of effective factors on e-loyalty and to improve e-commerce toward the advancement of customers and sellers purposes. E-loyalty process is divided in to three phases that include cognitive, effectiveness and action in this model. Seven selected components of this research are: demographic characteristics, web site and technology, sales promotion, products level offered to customer, e-security and e-trust, e-satisfaction and e-loyalty. Case study of this research was performed in Sepahan Cement Company of Isfahan with about 115 questionnaires. Data analysis was performed by the Structural Equation Model (SEM) and LISREL software. The results of this research show that demographic characteristics of the customers and e-security and e-trust are effective factors on e-loyalty.
\end{abstract}

Keywords: e-loyalty, e-commerce, Structural Equation Model

\section{Introduction}

Fact development of Internet and technology, the change of competition policies in companies and financial interactions by electronic means drew the attention of most people toward this thought that how they can be profitable in e-commerce world of technology and communications. The subject of loyalty in Internet space or e-loyalty has attracted many parts of marketing studies toward itself because customer is the most important asset of the companies and customer retention causes more profitability and buyers by Internet can compare global goods whit each other with a little cost or without cost easily.

The development of customer loyalty is a strategic purpose for most companies and organizations, today most companies try retain customers and attain more share of each customer (Duffy, 2005). People can access to information and interact whit global business easily whit fast development of e-commerce. Its combination with economic emergence and efficient electronic abilities causes the popularity of online sales (Tu, 2012).

The purpose of this research is to identify and extract effective factors and indexes on e-loyalty in productive companies and in the company under study (Sepahan Cement of Isfahan). In addition, one of expected purposes of this research is to improve e-commerce toward the advancement of customers and sellers purposes.

\section{Research literature}

The emergence of loyalty concept comes back to early decade of 1940. This structure shows two separate concepts including brand preferences (attitude loyalty) and market share (behavioral loyalty) (Rundle-Thiele, 2001). Many researchers have offered various definitions in this area, Some researchers believe loyalty is successive buying of the customer (Jacoby, 1978) and the investigation of buying behavior of the customer is the investigation of the loyalty (Kuehn, 1962). Others believe attitude element is effective along whit behavioral element for the assessment of the 
loyalty (Dick Alan, 1994). The most comprehensive definition has been offered by Richard Oliver; he believe loyalty is described as a strong commitment for repeated buying of the same product or for services in future in spite of marketing efforts of other competitors (Oliver, 1999).

Demographic characteristics. Customer loyalty depends on his personal characteristics. Chen and Hitt (2002) conducted a research for the determination of the loyalty of online customers. They investigated personal characteristics of the customers in buying from online shopping and concluded demographic characteristics affect shop choices (Tsai, 2009). Butch Rice and Jan Hofmeyer believe younger customers are less committed to brand compared with older customers (Clark, 2007).

Website and technology. Website is the first communication channel of the customer and company or organization in e-business. Website plays a main role in customer loyalty if it can meet customer needs in first step. Kim, Jin and Swinney (2009) conducted a research with the purpose of the integration of the model of e-loyalty development process. They conducted on analysis with the focus on four dimensions of retailing quality. That moved toward website operation. These dimensions include performance/ validity, website design, security/ privacy and quick response. They concluded the design of website has a significant effect on e-satisfaction and e-satisfaction has a significant effect on the process of e-loyalty development. They used the method of Structural Equation Model in this analysis (Kim, 2009).

Offered products /services level to customer. Romulo (2007) conducted a research in order to prove a strong relationship between the quality of offered services and e-loyalty. In this research, data was evaluated by Structural Equation modeling (SEM). The results of this research show e-service quality affects e-loyalty (Romulo, 2007).

$E$-trust and E-security. Trust is loyalty drive and it is effective for long-term communication in business. Trust is defined as being satisfied with someone who is considered as business partner (Rachjaibun, 2007). Wu, Tang and Tsai (2005) conducted a research whit the aim of communications by e-trust, e-satisfaction and e-loyalty. Their research shows the behavior of online customer, e-trust, e-satisfaction and e-loyalty based on the Technology Acceptance Model (TAM). Collected questionnaires were about 1285. These questionnaires were distributed among online customers of estores in Taiwan. They used the Structural Equation Model for the analysis of the data. The results showed e-trust has significant effect on the facilitation of customer e-satisfaction and e-loyalty (Tang, 2005)

E-satisfaction. Satisfaction is an effective response for buying states (Chang, 2008). Also satisfaction is the result of customer experience during different stages of buying (Lin, 2011). E-satisfaction includes judgements customers about Internet experience so that they compare these experiences with the experiences from traditional services provider or retail shops (Rachjaibun, 2007). Srinivasan and Anderson investigated customer loyalty in the area of e-commerce and they described customer loyalty as a favorable state towards e-retailing that leads to the repetition of buying behavior. They also investigated the effect of customer satisfaction on their loyalty in the area of e-commerce and suggested customer satisfaction depends on last buying experience from a certain e-commerce company (Anderson, 2003).

E-loyalty. E-loyalty includes desirable tendency of the customer towards e-retailing and its result is the repetition of buying behavior. E-loyalty of the customer has significant difference with traditional environment because Internet users can access to web sites just whit a click (Jeon, 2009). The loyalty of the customer is one of important drivers for success of e-commerce (Rachjaibun, 2007). In the world of real business, Oliver showed loyalty framework from recognition to action based on the pattern of recognition-effect-effort in 1997. This model includes successive stages of recognition (loyalty to information such as price, characteristics), effect (loyalty to interests), effort (loyalty to tendency) and action (loyalty to action). Oliver say consumers become loyal to recognition feeling and then, their loyalty extends to the concept of effect, effort and behavioral manner. Behavioral manner is described as action faculty (Chang, 2008).

\section{Conceptual model of research}

Research model is considered in this section in order to better understand e-loyalty and investigate the hypotheses of the research based on it. The purpose of this research is to identify effective factors on e-loyalty. Seven components were extracted by different papers and research in this area. Five indexes of each component were designed for the compilation of first questionnaire. First questionnaire were completed via 14 experts in the area of the sale of ecommerce. Then, indexes priority was selected by Friedman test and 3 indexes for each component with the most priority were chosen that are show in table (1). 
Table 1: Effective indexes and factors on e-loyalty

\begin{tabular}{|c|c|c|c|}
\hline Factor & Index & Factor & Index \\
\hline 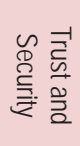 & $\begin{array}{c}\text { - respect for customers privacy } \\
\text { - no abuse account information of customers } \\
\text { - approved by legal reference }\end{array}$ & 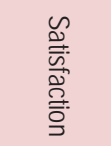 & $\begin{array}{c}\text { - maximum satisfaction level } \\
\text { - investigation of complains and criticism of } \\
\text { customer } \\
\text { - providing facilities of buying }\end{array}$ \\
\hline 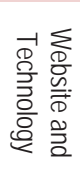 & $\begin{array}{c}\text { - fast response and strong action } \\
\text { - update information and services of website } \\
\text { - methods of easy paying }\end{array}$ & 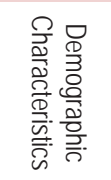 & $\begin{array}{l}\text { - customer age } \\
\text { - Internet experience of customer } \\
\text { - no risk of customer }\end{array}$ \\
\hline 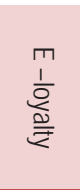 & $\begin{array}{l}\text { - brand } \\
\text { - personalization of web pages } \\
\text { - product reliability }\end{array}$ & 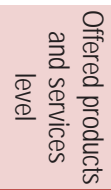 & $\begin{array}{l}\text { - goods quality } \\
\text { - post-sale services } \\
\text { - customization in production level }\end{array}$ \\
\hline
\end{tabular}

After the extraction of the factors and indexes, research model was designed as shown in figure (2). This process has been divided in to three phases of cognitive, effectiveness and action (Chang, 2008).

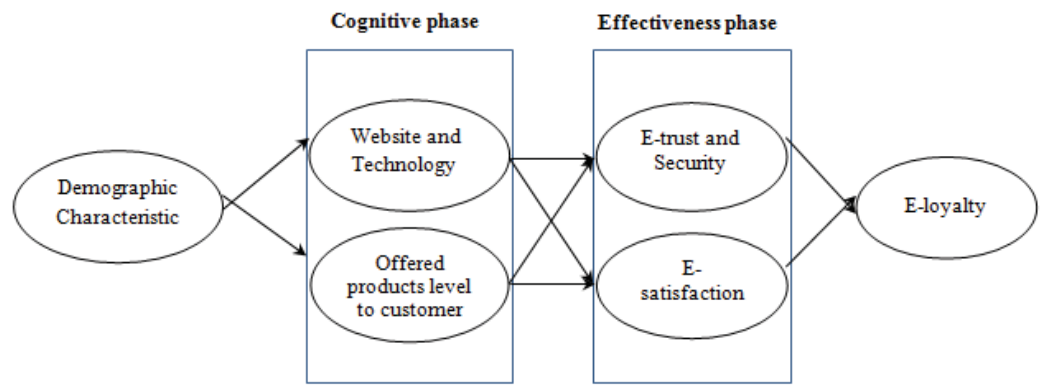

Figure 1: Theoretical framework of the research

\subsection{Hypothesis development}

In most papers, demographic characteristics of respondents such as age, education, gender, Internet experience, etc, are considered but their relationships with other factors have not been investigated. In limited studies such as Miyazaki (2001), Rodger (2003), Zhou and Ulbrich (2011), the effects of demographic variables on e-loyalty have been determined. Also Kim (2004) investigated the effects of demographic variables on online shopping. But because the effects of demographic characteristics on website and technology, offered products level to customer and sales promotion have not been investigated completely, we consider following hypothesis in this research:

Hypothesis 1: website and technology are affected by demographic characteristics.

Hypothesis 2: offered products level is affected by demographic characteristics of the customers.

Mcknight (2002), Floh (2006) and I.Eid (2012) pointed out direct effect of website quality on customers trust. Roy (2001) and Cyr (2008) also evaluated the relationship between e-commerce website user interface quality and trust. Hise and szymanski (2000), Byoungho Jin, Jiyoung Kim and Janel Swinney (2009) pointed out positive effect of website design on e-satisfaction. Montoy-Weiss (2003) mentioned the variables of website design and graphic style affect esatisfaction. Devaraj (2002), Shankar (2003), Cai, Xu (2006) and many other researcher suggested the effect of information content and easy navigation feature of the website on e-satisfaction. Lin (2007) suggested the effect of website quality dimensions including information/ services quality and system quality on customer satisfaction. Therefore 
it is hypothesized that:

Hypothesis 3: website and technology have significant effect on e-trust and e-security of the customers.

Hypothesis 4: website and technology have significant effect on e-satisfaction.

Madu (2000) suggested online services should be updated and reliable in order to attract customers. Urban, Reichheld and et al (2000) on time delivery of the product affects e-trust of the customers. In most papers, the relationship between services/products quality and satisfaction or e-satisfaction has been investigated such as Kim and park (2003), Zeithamel and Bitner (2003), Chang, Chen and Huang (2011). In some papers, the relationship between on time delivery of the product and satisfaction has been investigated such as Collier and Bienstock (2006). Ki Han Chung (2008) suggested five attributes of e-retailing (shopping convenience, product selection, price, customization and informativeness) affected e-satisfaction. Therefore, following hypotheses are consistent with current study:

Hypothesis 5: offered products level to customer can affect e-trust and e-security of the customers.

Hypothesis 6: offered products level to customer increase e-satisfaction.

Many researchers have conducted research about the effect of customers trust and satisfaction in the area of traditional marketing and e-commerce. Some researchers such as Reichheld, Hopton, Markey (2000), Cyr (2008), Kim, Jin and Swinney (2009) and others evaluated positive effect of e-trust on e-loyalty of the customers. Some researchers such as Anderson and Srinivasan (2002), Rexha (2003), Gummerus (2004), Lai (2007), Chang and Chen (2008), Huang (2011) suggested the effect of e-satisfaction on e-loyalty. Therefore, two hypotheses should be investigated:

Hypothesis 7: e-trust and e-security have significant effect on e-loyalty of the customers.

Hypothesis 8: e-satisfaction improves e-loyalty of the customers.

\section{Research methodology}

This research is quantitative because the relationship between e-loyalty and other factors are shown as linear structure. We also want to find the relationship between related premises by hypothesis. This research can be classified as functional research in terms of purpose and as surveying-descriptive research in terms of method. Statistical society of this research includes informatics experts, sales experts and cement buyers of Sepahan Cement of Isfahan. The method of random sampling was used for people selection. Collected questionnaires were 115.

Structural Equation Model (SEM) is used for the analysis of the data. Software LISREL is used for data analysis and the confirmation of conceptual model at the compilation of conceptual model. Structural Equations Modeling is a multivariate analysis technique. It is a general strong technique from multivariate regression family and the expansion of general linear model. Researcher can test a set of regression equations simultaneously by this technique. Multivariate analysis refers to a series of analysis methods that their main characteristic is simultaneous analysis of " $\mathrm{K}$ " independent variables and " $\mathrm{n}$ " dependent variables. Structural Equations Modeling is a comprehensive statistical approach for testing hypothesis about the relationships between manifest and latent variables. It is called covariance structural analysis or causality modeling or LISREL. Today popular term is Structural Equations Modeling or SEM. Covariance structures analysis is one of main analysis methods of different variables that shows simultaneous effects of variables in a structure based on theory (Mueller, 1996).

Cronbach alpha method has been used in this research in order to investigate questionnaires reliability. Construct validity was used in order to investigate questionnaire validity. Questionnaire validity refers to the ability of the tool for the measurement of the property that questionnaire has been designed for its measurement. This validity includes apparent validity, context validity, construct validity, predictive validity and etc (Adhami, 2005).

\section{Data analysis}

One of the methods of reliability measurement is the use of Cronbach alpha coefficient. If alpha value is above 0.7, reliability is good and if alpha value is between 0.5 and 0.7 , reliability is medium. The questionnaire has no reliability when alpha value is below 0.5 . Questionnaire reliability was measured by Cronbach alpha coefficient and saftware SPSS, version 19 in this research. The value of 0.806 was obtained. This value shows suitable and acceptable reliability for the questionnaire. Following table shows this value.

Research model has been investigated by Structural Equations Modeling method and software output has been shown in Figure (2). 


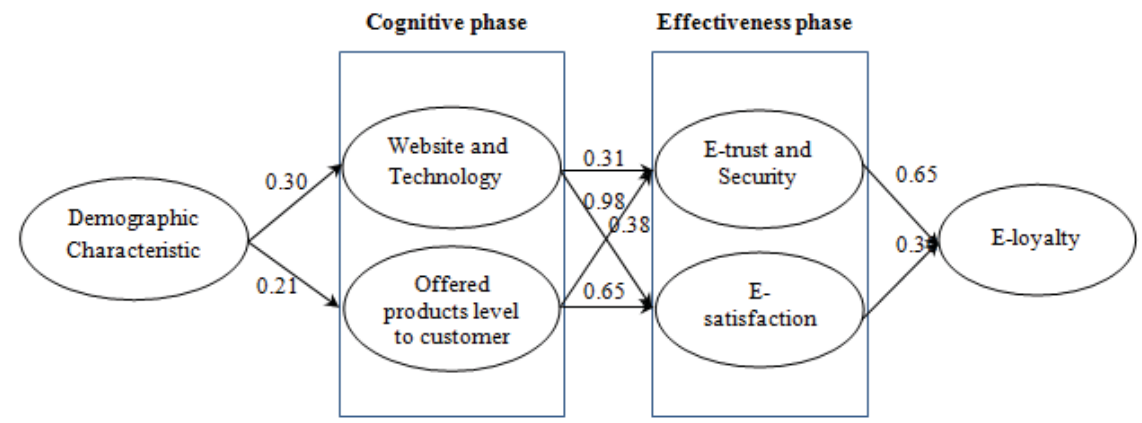

Figure 2: measurement model of research variables

The most important fit index of the model is test $X^{2}$ but a series of secondary indexes are introduced because $X^{2}$ test is effective under certain conditions and sometimes these conditions are not realized. The most important indexes include Goodness of Fit Index (GFI), Adjusted Goodness of Fit Index (AGFI) and Root Mean Square Residual (RMSR). $X^{2}$ Test shows difference between data and model. So, less value of this test shows better result. Some researchers suggest the index resulted from Chi-Square divided by Degree Freedom (DF) instead of above mentioned index. The value of this index should be below 3 (Paul, 1994).

A main question arises here: Is this measurement model considered as a suitable instrument for the measurement of e-loyalty $X^{2}$ Statistic and other criteria of Goodness of Fit should be investigated in order to answer this question. Fit indexes of the model show measurement model of information variable is suitable because the ratio of Chi-Square to Degree freedom is below 2.

According to software output, Goodness of Fit Index (GFI) is 0.78 , Adjusted Goodness of Fit Index is 0.71 , and the model is in good condition in terms of these two values. Root Mean Square Residual (RMSR) equals 0.09. Smaller value of RMSR shows better fitness of the model and data.

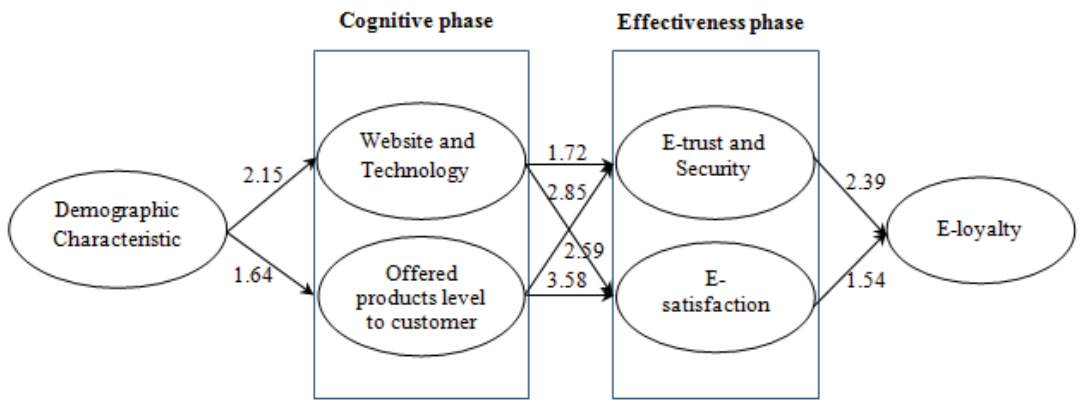

Figure 3: Measurement model of research variables in the state of T-Value

Research hypothesis are investigated with regard to figure 2 and figure 3 . The relationship between demographic characteristics and website and technology has path coefficient of 0.30 and significance value of 2.15. Therefore, hypothesis 1 is acceptable. The relationship between demographic characteristics and offered products level to customer has path coefficient of 0.21 and significance value of 1.64. Therefore, hypothesis 2 is not accepted.

The relationship between website and technology with e-trust and e-security has path coefficient of 0.31 and significance value of 1.72 . Thus, hypothesis 3 is not accepted. The relationship between offered products level to customer with e-trust and e-security has path coefficient of 0.98 and significance value of 2.85 . Therefore, hypothesis 5 is accepted.

The relationship between website and technology with e-satisfaction has path coefficient of 0.38 and significance value of 2.59. So, hypothesis 4 is accepted. The relationship between offered products level to customer with esatisfaction has path coefficient of 0.65 and significance value of 3.58. So, hypothesis 6 is accepted. 
The relationship between e-trust and e-security with e-loyalty has path coefficient of 0.65 and significance value of 2.39. So, hypothesis 7 is accepted. The relationship between e-satisfaction with e-loyalty has path coefficient of 0.30 and significance value 1.54. Therefore, hypothesis 8 is not accepted.

\section{Discussion and conclusion}

In this research, the effects of some factors that had not been investigated well previously were considered. In the path analysis, the effects of demographic characteristics of the customers on website and technology and offered products/ services level to customer were measured and the results showed it is positive effect on website and technology directly and on e-loyalty indirectly. Customers with more internet experiences are attracted by online shopping compared with other customers. Therefore, senior managers of the company should try to have efficient sales website in terms of update information and services website, methods of easy paying and fast response and strong function of web pages.

In this way, the customers, who compare products and services by internet sales gate, refer to efficient website in order to meet their needs. Researchers such as Ulbrich, Zhou and Rodger suggested the effects of demographic characteristics on e-loyalty that are consistent with this research. With regard to demographic characteristics, managers should try to attract young people who have more Internet experiences in order to attract customers and make them loyal and achieve their goals. The results of this research show e-trust and e-security affect e-loyalty development directly. Researchers such as Reichheld, Rexha and Kim found the same results in their research. Therefore, if online companies are approved by legal authorities and if they respect the privacy of the customers and do not abuse their account information, customers are encouraged to buy by their website because they trust them and give accounts information. In contrast to studies such as Anderson, Srinivasan, Chen and Huang that emphasized the effect of e-satisfaction on eloyalty. In this research, e-satisfaction does not have significant effect on e-loyalty as almogayan and pleshko (2010) did not find relationship between customer satisfaction and loyalty. Although website and technology do not affect e-loyalty directly, they affect e-loyalty by e-trust and security indirectly. Therefore, companies should be careful about website design.

Online companies that want to have satisfied customers should focus on website and technology and offered products/ services level to customer in order to make customer satisfied. But if they want to have loyal customers, they should make customers confident.

Note that regard to ecommerce in cement Industry in Iran are not developed as well, the results in other industries such as book selling and so on or in the other countries may be differ.

\section{Reference}

Adhami A. Nakhaee N. Fasihi Harandi T \& Fattahi Z. (2005), Preliminary assessment of the validity and reliability of the evaluation questionnaires by the students regarding methods of the faculty members of Kerman university of medical sciences in 20022003. Journal of Medical Education Center, 1, 121-129.

Anderson R.E \& Srinivasan, S. S. (2003), E-satisfaction and e-loyalty: A contingency framework, Journal of Psychology \& Marketing, 20 (2), 123-138.

Bentler P.M \& K-H, Y. (1999), Structural equation modeling with small samples: test statistics, Journal of Multivariate Behavioral research, 181-197.

Chang H. H \& Chen S.W. (2008). The impact of customer interface quality, satisfaction and switching costs on e-loyalty: Internet experience as a moderator, Journal of Computers in Human Behavior, 2927-2944.

Dick Alan S. B. K. (1994), Toward an Integrated Conceptual Framework, Journal of Academy of Marketing Science, 22, 99-114.

Duffy D.L. (2005). The evolution of customer loyalty strategy. Journal of Consumer Marketing, 22.

Anderson R. E \& Swaminathan S. (2011), Customer Satisfaction and Loyalty in E-Markets: A PLS Path Modeling Approach, Journal of Marketing Theory and Practice, 221-234.

Eskandarikhoee J. (2010), Influential factors of customer e-loyalty in Iranian e-stores, Master of Thesis.

Ilsever J, Cyr D \& Michael P, (2007), Extending models of flow and e-loyalty, Forthcoming in Journal of Information Science and Technology.

Jacoby J, Chestnut R. W \& William A. F. (1978), A Behavioral Process Approach to Information Acquisition in Nondurable Purchasing, Journal of Marketing Research, 15, 532-544.

Jeon M.M. (2009), Impact of perceived website service quality on customer e-loyalty on a lodging website, Graduate Theses and Dissertations.

Khan I. (2012). Impact of Customers Satisfaction and Customers Retention on Customer Loyalty, International Journal of Scientific \& Technology Research, 2, 106-110.

Kim J, Jin B. L \& Swinney J. (2009). The role of e-tail quality, e-satisfaction and e-trust in online loyalty development process, Journal of 
Retailing and Consumer Services, 239-247.

Kuehn A. A. (1962). Consumer Brand Choice as a Learning Process, Journal of Advertising Research, 2, 10-17.

Lee-Kelley L, Gilbert D \& Mannicom R . (2003). How e-CRM can enhance customer loyalty. Journal of Marketing Intelligence \&Planning, 21(4) , 239-24.

Mueller R. B. (1996), Principe of Structural Equations Modeling, USA.

Oliver R.L. (1999). Whence consumer loyalty?. journal of Marketing, 63, 33-44.

Paul K. (1994). An easy guide to factor analysis.

Rachjaibun N. (2007). A study of Antecedents of e-relationship quality in hotel website, Master of Thesis.

Romulo C \& Oliveira D. (2007), Evidences from link between quality and loyalty in eservice: an empirical study, journal of Revista Eletronica Sistemas \& Gestao, 1-15.

Rundle-Thiele S \& Mackay M.M. (2001). Assessing the performance of brand loyalty measures, journal of service marketing, 15,529546.

Tang T-W, Tsai C-H, Wu W-P. (2005).The Relationships among Trust, E-Satisfaction, E-Loyalty, and Customer Online Behaviors. Proceedings of the Fifth International Conference on Electronic Business, 788 - 794.

Tsai H-T, Huang H-C. (2009).Online consumer loyalty: Why e-tailers should seek a high-profile leadership position, Computers in Human Behavior, 1231-1240.

Tu C-C, Fang K \& Lin C-Y. (2012), Perceived Ease of Use, Trust, and Satisfaction as Determinants of Loyalty in e-Auction Marketplace, Journal of computers, $3,645-652$.

Clark, P. (2007). The six key factors that influence customer loyalty, The Loyalty Guide, Volume II; Wise Research Limited.

Kotler, P. (1996). Marketing management, Prentice-Hall.

Williams, M. (1995). Interactive Marketing, Prentice-Hall.

Whith, S. (2003). Reward loyal customers with sales promotion, Retrieved, 5-27.

Lin, C. -C.; Wu, H.-Y. and Chang, Y.-F. (2011).The critical factors impact on online customer satisfaction, Journal of Procedia Computer Science, 3, 276-281. 